\title{
DEVELOPING LISTENING MATERIALS FOR THE TENTH GRADERS OF ISLAMIC SENIOR HIGH SCHOOL
}

\author{
Alimin \\ Universitas Qomaruddin Gresik \\ alimin@uqgresik.ac.id
}

\begin{abstract}
This study is intended to develop listening materials. The research problem was "What is the appropriate listening material for the tenth graders of Islamic Senior High School of MA Ma'arif 7 Banjarwati. The study was designed in the form of Research and Development (R \& D). The steps were need analysis, developing listening materials, expert and teachers' validation, revision, try out, and final product. In collecting the data, several instruments were used. They are try-out, questionnaire, observation, and field notes. After the materials have been developed and validated by the expert and teacher, then it is tried out. Ten students were involved the try out. After the try out, the students stated their opinion. For the attractiveness, clarity of the recording, speed of delivery, vocabulary usage, and difficulty. Most the students stated that the materials were very good. For the result of the try out, the students made the most mistakes on ticking true or false activities. The steps of the research are need analysis, developing materials, expert and teachers' validation, revision, try out and the final product. The product of this study is teacher's book, student's worksheet, and the listening materials. The materials are compiled in the form of CD. They are the language, length, content, style, and speed of delivery, the style of delivery and the quality of the recording. The materials are suitable with the students' need, interest, and level of students' ability in English. Listening activities can motivate students' interest in learning English. Listening materials can give teachers a lot of input to be better in preparing listening activities.
\end{abstract}

Keywords: Listening, Development, Listening Materials.

\section{INTRODUCTION}

Listening is the most important skill in learning language of other skills like speaking, reading, and writing. This skill is considered to be the most important because all people in their daily life listen every day. They are listening to people speaking, tape recorder, radio, and television. According to Nunan (1999) listening is the Cinderella skill in second language learning. The Cinderella skill here means that listening is not really taught a lot. Another reason why listening is important is that the ability to understand what others say is essential for communicative interaction. People interact in their daily life with others. During the interaction process, people are listening to others then followed by speaking. Thus, it can be inferred that listening comes earlier than speaking. 
Another fact showing how listening is more prominent than speaking is in the process of teaching and learning in the classroom. In that process, teachers start speaking and students listen to their teacher. Furthermore, in language learning, most activities are spending in listening process. It has been claimed that over 50 percent of the time that students spend functioning in a foreign language will be devoted to listening (Nunan, 1998). The frequency of students to listen is much more than to speak in the classroom. But mostly they listen to the teacher talking or explaining the lesson. It is very ironic to students when they have to study English because teachers talk a lot, reading the passage; tell a story or a joke, students just listen. It is not very good because what students hear is not native. By this process, the listening skill is often neglected in teaching and learning for foreign language.

As a skill which is frequently used in daily life, listening mostly covers every aspect of life. In spite of the importance of listening, the skill is considered one of the most neglected and difficult skills in language teaching. The reason is because the teachers do not emphasize the listening objectives. Thus, most teachers just let the listening develop naturally. Another reason that listening is not emphasized is as the teachers do not have much experience in teaching effective listening. Teachers do not know the best way to teach it. Out of the four skills - listening, speaking, reading, and writing - listening is naturally considered as the primary skill in the acquisition of the native (first) language (Cahyono and Widiati., 2011:15). As a primary skill, it is very important to be taught but in reality, it is seldom taught even never at all. Therefore, listening has been neglected to a secondary position in the English language teaching classroom. In reality, in research, not many researchers are doing on listening skill they prefer doing research on speaking, reading, and writing. This phenomenon can be seen that not many books particularly available in listening skill. So, the teachers get difficulties in choosing the materials.

The listening materials basically almost involve many aspects of life. It means that they contain many things dealing with our daily lives. The materials are usually not well organized. In many cases it can be seen that sometimes the listener can predict what the speakers are going to say. In the same time, for many learners, listening to a taped message is more difficult than reading. Dealing with this case, some suggestions have been proposed by Fang (2008) as follows:

First, present students with different kinds of input, such as lectures, radio news, films, TV plays, announcements, everyday conversations, interviews, storytelling, English songs and so on. Second, attempt to discover visual aids or draw pictures and diagrams related to the listening topics to aid students to guess or imagine actively. Third, grade listening to the students' level, and offer authentic materials rather than idealized filtered samples. Forth, knowledge of structure is an important part of listening proficiency although most published materials underscore for the meaning of the passage rather than listening for the structure that clearly embodies the meaning. Thus, as teachers must understand and carefully choose what materials are going to be used in teaching listening.

Ideally, all skills have to be taught in learning languages. Most English teachers, including the researcher himself rarely teach listening skill to the students. Thus, the target of learning achievement is not able to be reached. Then students always feel bored in learning listening activities. They think listening is 
very, very difficult indeed. Mainly they do not like listening just because they are not accustomed to listen. Automatically students' speaking ability is not good.

The teaching of listening at the tenth graders does not make a good result of students' achievement. This is because the teachers rarely teach them listening, if so just listening to the songs only. The factors why the teachers rarely teach listening are because the materials are inadequate. Another factor is the teachers are low of payment so they are not motivated in providing good materials for teaching listening skill. Actually at MA Ma'arif 7 Banjarwati, there has been English laboratory and in this academic year there has been a multimedia room which can be used to teach listening well. Unfortunately, the usage of the room is less effective since the teachers do not take advantage of it.

Some previous studies in developing listening materials for language teaching have been done by Hartani (1999), Rosyidah (2002), and Zainuri (2008). In Hartani's study, the product of her study is still in the form of cassette for the students of secretary academic. In Rosyidah, (2002) the product is mostly in the form of monologue texts and consists of only one dialogue (conversation) text. In Zaenuri (2008) the product is specified on CD recorded materials, teachers' guide and students' worksheet. Something good is that the topics of the materials are relevant to the syllabus and the materials are good because they were recorded three times. Their researches are similar to the researcher's research. It is about developing listening materials.

\section{THEORETICAL REVIEW}

\section{The Importance of Teaching Listening}

Listening is very active. As people listen, they process not only what they hear but also connect it to other information they already know. Since listeners combine what they hear with their own ideas and experiences, in a very real sense they are "creating the meaning in their own minds" (Helgessen 2003).

While-listening activities are the real listening activities. In this step, students' comprehension is the most important one to be checked. The purpose in this activity is to check students' general understanding on what they are hearing. What the students hear is in the form of spoken text whether it is monologue or dialogue text. Harmer (2007) describes the text as text-related task. The textrelated tasks are 'any kind of follow up activity which might be either a response to a content of the text or a focus on aspects of language in the text' (Harmer, 2007).

\section{The English Standard of Content for Listening Skill}

The English standard of content of senior high school is almost the same as the English standard of content for junior high school. Both of them consist of four parts, i.e. background, objective, scope, and standard competence and basic competence. In the background, language learning becomes the vital one to support the success of study. It gives a lot of thing to be used in preparing better future because students are hoped to be able to know themselves, culture and others' culture. In addition, the language learning can help them to express idea and feeling, participate in community, and even can find and use their analytical and imaginative ability which are existed on themselves. As a means of 
communication orally and in written form, students are able to understand and express any information, thoughts, and improve knowledge, technology, and culture. All communicative skills are proved and developed into four skills, i.e. listening, speaking, reading and writing. These four skills are hopefully able to create discourse in community lives. Therefore, English is directed to improve those skills in order that the graduates can communicate and have a discourse in certain literacy level. The literacy level includes per formative, functional, informational, and epistemic levels. On level of per formative, people can read, write, listen and speak with used symbols. In functional level, people can use language to fulfill their daily lives such as read newspaper and so on. In informational level, people are hoped be able to access knowledge and science with language capability, while in epistemic level, people can use and express their knowledge into the target language. (Departemen Pendidikan Nasional 2006)

\section{The Nature of Listening Comprehension}

It has been claimed that over 59 percent of the time that students spend functioning in foreign language will be devoted to listening (Nunan, 1998). Listening is the nature precursor to speaking; the early stages of language development in person's first language are dependent on listening. Basically in learning anything or other skills in learning languages listening is the one to be the most important. Thus, listening is the way of learning language. It gives the learner information from which to build up the knowledge necessary for using language. When the knowledge has been built up, they begin to speak.

Anderson and Lynch (1998) distinguish between reciprocal and nonreciprocal listening. Reciprocal listening refers to those listening tasks where there is the opportunity for the listener to interact with other speakers, and to negotiate the content of the interaction. Non-reciprocal listening refers to tasks such as listening to the radio or a formal lecture where the transfer of information is in one direction only from the speaker to the listener.

\section{Micro and Macro Skills of Listening}

Brown (2007:308) explains some micro and macro skill of listening on a list which are very essential and give much benefit to a process of teaching language especially in listening. In this case they can help teachers on achieving maximum target in teaching listening by providing certain strategies on creating effective teaching process. The micro and macro skill of listening are as follows: (1) Retain chunks of language of different lengths in short term memory; (2) discriminate among the distinctive sounds of English; (3) Recognize English stress patterns, words in stressed and unstressed positions, rhythmic structure, into national contours, and their role in signaling information; (4) Recognize reduced forms of words; (5) Distinguish word boundaries, recognize a core of words, and interpret word order pattern their significance; (6) Process speed at different rate of delivery; (7) Process speed containing pauses, errors, corrections, and other performance variables; (8) Recognize grammatical word classes (nouns, verbs, etc.), systems (e.g., tense, agreement, pluralization), patterns, rules, and elliptical forms; (9) Detect sentence constituents and distinguish between major and minor constituents; (10) Recognize that a particular meaning may be expressed in different grammatical forms; (11) Recognize cohesive devices in spoken 
discourse; (12) Recognize the communicative functions of utterances, according to situations, participants, goals; (13) Infer situations, participants, goal using real word knowledge; (14) From events, ideas, etc., described, predict outcomes, infer links and connections between events, deduce causes and effects, and detect such relations as main idea, supporting idea, new information, given information, generalization, and exemplification; (15) distinguish between literal and implied meanings; (16) Use facial, kinesics, body language, and other nonverbal clues to decipher meaning; (17) Develop and use a battery of listening strategies, such as detecting key words, guessing the meaning of words from context, appealing for help, and signaling for comprehension or lack thereof.

\section{Process of Listening Comprehension}

Theoretically, listening comprehension is regarded as an active process in which individual concentrates on selected aspects of aural input, forms meaning from passages, and associates what he or she hears on existing knowledge. Commonly, as it is known well, that there are two process of listening comprehension. They are bottom up listening and top-down listening. These two processing intersect to develop an interactive processing which is called as the third type of listening comprehension. Fang (2008:22) states three points of listening comprehension as follows: Bottom up processing (the first type) is activated by the new incoming data. The features of the data pass into the system through the best fitting, bottom level schemata. Schemata are hierarchically formed, from the most specific at the bottom to the most general at the top. It acknowledges that listening is a process of decoding the sounds, from the smallest meaningful units to complex texts. Thus, phonetic units are decoded and connected together to construct words, words are connected together to construct phrases, phrases are connected together to construct utterances, and utterances are connected together to construct complete, meaningful texts. That is to say, meaning is arrived at the last step in the process. This process is closely associated with the listener's linguistic knowledge. However, bottom-up processing has its weak points.

Understanding a text is an active process between the listener's previous knowledge and the text. Efficient comprehension that associates the textual material with listener's brain doesn't only depend on one's linguistic knowledge. Top-down processing (second type) is explained as employing background knowledge in comprehending the meaning of a message. Carrel and Eisterhold (1983:557) point out that in bottom up processing, the system makes general predictions based on a higher level, general schemata, and then search the input for information to fit into these practically satisfied, higher order schemata. In terms of listening, the listener actively constructs or reconstructs the original meaning of the speaker employing new input as clues. In this reconstruction process, the listener employs prior knowledge of the context and situation within which the listening occurs to understand what she/he hears. Context and situation involve such things as knowledge of the topic at hand, the speakers and their correlation with the situation, as well as with each other and previous events. We must realize if the incoming information the listeners hears is unfamiliar to him, it can't evoke his schemata and he can only depend heavily on his linguistic knowledge in language comprehension. 


\section{Problems of Teaching Listening}

Since the process of teaching listening is going, the learners are sometimes getting some mistakes in doing the exercise. It means that the learners get some problem in hearing recorded materials. Learners' problems are related to some difficulties faced by them in listening. Ur (2002:111) comments on learners' problems or difficulties in listening as follows:

a. Trouble with sounds. Since most listeners rely mostly on context for comprehension, they are often themselves unaware or inaccurate sound perception.

b. Have to understand every word. This is a very common problem, often unconsciously fostered by the teachers and/or listening comprehension materials which encourage the learner to believe that everything that is said bears (equally) important information. The effort to understand everything often results in ineffective comprehension, as well as feelings of fatigue and failure. We may need to give learners practice in selective ignoring of heard information-something they do naturally in their mother tongue. We should explain this point to the learners, and set them occasional tasks and ask them to scan a relatively long text for one or two limited items of information.

c. Can't understand fast, natural native speech.

d. Need to hear thing more than once.

e. Find it difficult to keep up

f. Get tired

\section{Types of Listening Comprehension Activities}

As in other skills, variety of listening activities is also classified into several kinds that differentiate from the level of difficulty. Some listening comprehension activities are proposed by Ur (2002:113). He classifies listening comprehension activities into four types as follows:

First, no overt response; the learners do not have to do anything in response to the listening; however, facial expression and body language often show if they are following or not. Three kinds of activities are classified in this type of activity. (1) Stories. Tell a joke or anecdote, retell a well-known story, read a story from a book; or play a recording of a story. If the story is well-chosen, learners are likely to be motivated to attend and understand in order to enjoy it. (2) Songs. Sing a song yourself, or play a recording of one. Note, however, than if no response is required learners may simply enjoy the music without understanding the words. (3) Entertainment: films, theater, video. As with stories, if the content is really entertaining (interesting, stimulating, humorous, dramatic) learners will be motivated to make the effort to understand without the need for any further task.

Second, short response; in this case, the learners make a response based on what they are hearing but the response itself is not long or even very long. Several categories of these types of activities are as follows: (1) Obeying Instruction. Learners perform actions, or draw shapes or pictures, in response to instruction. (2) Ticking off Items. A list, text or picture is provided: listeners mark or tick off words/components as they hear them within a spoken description, story or simple list of items. (3) True/False. The listening passage consists of a number if 
statements, some of which are true and some false (possibly based on material the class has just learnt). Learners write ticks or crosses to indicate whether the statements are right or wrong; or make brief response ('true! Or 'False!' for example); or they may stay silent if the statements are right; say 'No!' if they are wrong. (4) Detecting mistakes. The teacher tells a story or describes something the class knows, but with the number of deliberate mistakes or inconsistencies. Listeners raise their hands or call out when they hear something wrong. (5) Cloze. The listening text has occasional brief gaps, represented by silence or some kind of buzz. Learners write down what they think might be the missing words. Note of the text is recorded, the gaps have to be much more widely spaced than in a reading one; otherwise there is not enough time to listen, understand, think of the answer, and write. If you are speaking the text yourself, tan you can more easily adapt the pace of your speech to the speed of learner response. (6) Guessing definition. The teacher provides brief oral definition of a person, place, thing, action or whatever; learners write down what they think it is. (7) Skimming and Scanning. A not-too-long listening text is given, improvised or recorded; learners are asked to identify some general topic or information (skimming), or certain limited information (scanning) and note the answer (s). Written questions inviting brief answers may be provided in advance; or a grid, with certain entries missing; or a picture or diagram to be altered or completed. Third, Longer responses.

\section{METHOD}

The research design of this study is Research and Development (R\&D). As stated by Borg and Gall (1983:772) cited in Latief.M. A (2010:101) research and development (R\&D) is a process used to develop educational and validate educational products. The study is intended to develop and produce the materials which are used in school. The materials will be developed are listening materials for the tenth graders of $M A$ Ma'arif 7 Banjarwati.

The development process of the materials in this study follows Hyland's model (2003). The development includes the process in modifying the available sources by adapting the materials in the ways of adding, deleting, modifying, simplifying, and reordering the materials.

The procedure in developing listening materials at $M A$ Ma'arif 7 Banjarwati is through some stages consisting of Need Analysis, Developing Listening Materials, and Expert and Teacher's Validation. Procedures used to collect information about learners' need are known as needs survey (Richards, 2001). Needs survey is used in a number of purposes in language teaching. For instance, it is used to identify whether the materials in language teaching process is appropriate or not, to give the answer on students' need in developing materials in teaching, and to find particular problems of the students related to their experiences in learning.

In needs survey, three instruments are used to collect the data. The instruments are questionnaire, interview guide, and field notes. As the first instrument used, questionnaires are distributed to the tenth graders of $M A M a$ 'arif 7 Banjarwati and English teachers. Besides questionnaires, interview is also used to get the data. The interview is done to the English teachers. It is used to get information about the adequacy of listening materials and also to the listening materials needed. The third instrument used in needs survey is observation. In 
observation, the researcher uses field notes to notice basic important thing in line with the listening process to develop listening materials.

In developing the materials, mapping of the materials is done at first. The map here consists of a topic, listening aims, indicators, main activities and added with the extension activities. The topics are based on the Standard of Content and syllabus used for the tenth graders. While the activities in listening materials which will be developed, are based on the students' and teachers' suggestion. Vocabulary building activity is added before the students listen to the materials beside extensive activities. After the materials are developed and before they are tried out, the materials will be given to the experts and teachers to be validated. In research and development ( $R \& D$ ), the try-out should be carried out to know the quality of the product. The judgment of the quality is based on the practicality, effectiveness, clarity of the recording, attractiveness, speed of delivery, and level of difficulty of the materials. During the try-out, the researcher just observes the implementation of the materials taught by the selected teacher. One teacher is selected to do the try-out process. The selection is based on the length of the teacher's experience in teaching English. The purpose of doing the try-out is to obtain the information deals with the practicality and effectiveness of the materials developed.

The subjects of the try-out are the English teachers and the students of the tenth graders of $M A$ Ma'arif 7 Banjarwati. One English teacher was selected to do the try-out. The selected teacher is chosen from the length of the experience he/she teaches English at the tenth graders. The main subjects of the try-out are the tenth graders of MA Ma'arif 7 Banjarwati in the academic year 2017/2018. In selecting the class for the try-out, the simple random sampling was used. Then, the stratified sampling is used to choose ten students to do the try-out. The stratification is based on the students' competence in English. In this case, the students are classified into five categories based on the level of students' competence i.e. very clever, clever, fair, poor, and very poor. From each level of the competence, two students were chosen randomly by the lottery then they participated the try-out.

To collect the data during the try-out, questionnaire, observation, and field notes are used. The questionnaire is distributed to the teacher and students after the try-out are finished. For the teachers, the questions deal with the practicality and effectiveness of the materials. Practicality here is intended to know whether the teacher feels easy to implement the materials and for the effectiveness deals with the benefits of using the materials in teaching English especially in listening skill. The observation is the second instrument to collect the data during the tryout. After all the data have been collected, then it is presented. In presenting the data, the researcher uses different ways. The data obtained from the questionnaires of the students, are calculated in percentage. The data obtained from questionnaires, interview, and observation, are presented in the form of qualitative way in which the data are presented descriptively. 


\section{FINDING AND DISCUSSIONS}

\section{The Result of the Needs Analysis}

The result of the observation showed that the tenth graders of MA Ma'arif 7 Banjarwati was never taught listening materials. It was because there was no listening materials which were appropriate with the curriculum provided by the school. Therefore, the researcher conducted the research on developing listening materials there in order that the teaching of listening could be implemented and the materials used appropriate with the suitability with the existed curriculum. So, developing listening materials need to be done strongly. Two main sources were considered having very important role in this stage. They were the teachers and the students. Both of them were given questionnaires. The teachers said that most the students had been learning English since primary school. Their English were mostly not very good, even poor. During the tenth period, they were never taught listening skill. To generate their motivation, providing good materials was really needed especially the primary skill among four skills in English.

\section{The Developed Materials}

The result of the developed materials consisted of 13 units. The materials were in the form of teacher's book and students' worksheet. The teacher's book and the students' worksheet were the same for the activities in each unit. For teacher's book, it contained teachers' note and recording script. The recording were taken from internet and listening book. The developed materials can be seen on the following maps of the materials on each unit and map of the recording on CD.

Table 1: Map of the Materials on Each Unit.

\begin{tabular}{|c|c|c|c|c|}
\hline UNIT & TOPICS & $\begin{array}{c}\text { LISTENING } \\
\text { AIMS }\end{array}$ & MAIN ACTIVITIES & $\begin{array}{l}\text { EXTENSION } \\
\text { ACTIVITIES }\end{array}$ \\
\hline 1 & $\begin{array}{l}\text { Greeting and } \\
\text { partings }\end{array}$ & $\begin{array}{l}\text { Task 1: listening } \\
\text { for specific } \\
\text { information - } \\
\text { completing gaps. } \\
\text { Task 2: listening } \\
\text { for specific } \\
\text { information - } \\
\text { ticking yes/no } \\
\text { questions. } \\
\text { Task 3: listening } \\
\text { for specific } \\
\text { information - } \\
\text { answering } \\
\text { questions. }\end{array}$ & $\begin{array}{l}\text { - Listening to the } \\
\text { recording and } \\
\text { completing the gaps } \\
\text { in the table. } \\
\text { - Listening to the } \\
\text { short conversation } \\
\text { and answer the } \\
\text { questions with yes } \\
\text { or no answer. } \\
\text { Listening to the } \\
\text { short conversation } \\
\text { again and answer } \\
\text { the questions } \\
\text { correctly. }\end{array}$ & $\begin{array}{l}\text { In pairs, tell students to } \\
\text { write a simple dialogue } \\
\text { about greetings and } \\
\text { partings as the example } \\
\text { from task } 2 \text { then let them } \\
\text { perform in front of the } \\
\text { class pairs by pairs. }\end{array}$ \\
\hline 2 & Introduction & $\begin{array}{l}\text { Task 1: listening } \\
\text { for specific } \\
\text { information - } \\
\text { completing gaps. } \\
\text { Task 2: listening } \\
\text { for specific } \\
\text { information - } \\
\text { matching half } \\
\text { sentences. }\end{array}$ & $\begin{array}{l}\text { - Listening to the } \\
\text { several } \\
\text { conversations to fill } \\
\text { in the blanks. } \\
\text { - Listening to the } \\
\text { recording and } \\
\text { match half } \\
\text { sentences. }\end{array}$ & $\begin{array}{l}\text { One by one, students } \\
\text { introduce themselves in } \\
\text { front of the class then in } \\
\text { pairs, they introduce } \\
\text { someone to someone else. }\end{array}$ \\
\hline
\end{tabular}




\begin{tabular}{|c|c|c|c|c|}
\hline 3 & Announcement & $\begin{array}{l}\text { Task 1: listening } \\
\text { for specific } \\
\text { information - } \\
\text { completing } \\
\text { chart. } \\
\text { Task 2: listening } \\
\text { for specific } \\
\text { information - } \\
\text { multiple choice. } \\
\text { Task 3: listening } \\
\text { for specific } \\
\text { information - } \\
\text { putting the } \\
\text { number in the } \\
\text { correct places. }\end{array}$ & $\begin{array}{l}\text { - Listening to the } \\
\text { announcement of } \\
\text { job vacancy to } \\
\text { complete the chart. } \\
\text { - Listening to the } \\
\text { announcement and } \\
\text { choose the best } \\
\text { answer. } \\
\text { - Listening again to } \\
\text { the announcement } \\
\text { and putting the } \\
\text { number in the } \\
\text { correct places. }\end{array}$ & $\begin{array}{l}\text { Divide the students into } \\
\text { five groups then give out } 5 \\
\text { different pictures where } \\
\text { they usually hear the } \\
\text { announcement. Tell them } \\
\text { to make a certain question } \\
\text { related to the picture in } \\
\text { each group. Encourage } \\
\text { them to have a speaking } \\
\text { activity from one group to } \\
\text { another group in turn. }\end{array}$ \\
\hline 4 & $\begin{array}{l}\text { Talking about } \\
\text { past event }\end{array}$ & $\begin{array}{l}\text { Task 1: listening } \\
\text { for specific } \\
\text { information - } \\
\text { completing gaps. } \\
\text { Task 2: listening } \\
\text { for specific } \\
\text { information - } \\
\text { answering } \\
\text { questions. }\end{array}$ & $\begin{array}{l}\text { - Listening to short } \\
\text { conversations to fill } \\
\text { in the gaps. } \\
\text { - Listening to the } \\
\text { monologue text } \\
\text { then answer the } \\
\text { questions correctly. }\end{array}$ & $\begin{array}{l}\text { Give out a blank of paper } \\
\text { to each student and tell } \\
\text { them to write their funny } \\
\text { experience in a short } \\
\text { paragraph. Choose the best } \\
\text { five among of them then } \\
\text { tell them to read in front of } \\
\text { the class. Encourage other } \\
\text { students to ask some } \\
\text { questions related to their } \\
\text { experience. }\end{array}$ \\
\hline 5 & $\begin{array}{l}\text { Making } \\
\text { invitation }\end{array}$ & $\begin{array}{l}\text { Task 1: } \\
\text { Listening for } \\
\text { specific } \\
\text { information - } \\
\text { completing gaps } \\
\text { Task 2: } \\
\text { Listening for } \\
\text { specific } \\
\text { information - } \\
\text { ticking true or } \\
\text { false }\end{array}$ & $\begin{array}{l}\text { - Listening to several } \\
\text { short dialogues to } \\
\text { fill in the gaps. } \\
\text { Listening the } \\
\text { dialogue and stating } \\
\text { if it is true or false } \\
\text { based on the } \\
\text { dialogue. }\end{array}$ & $\begin{array}{l}\text { In pairs, give the students } \\
\text { pictures of certain } \\
\text { situation such as wedding } \\
\text { party, birthday party, } \\
\text { reunion, etc. Ask them to } \\
\text { write a simple dialogue or } \\
\text { conversation related to the } \\
\text { picture provided. }\end{array}$ \\
\hline 6 & $\begin{array}{l}\text { Making or } \\
\text { declining } \\
\text { appointment }\end{array}$ & $\begin{array}{l}\text { Task 1: } \\
\text { Listening for } \\
\text { specific } \\
\text { information - } \\
\text { answering } \\
\text { questions } \\
\text { Task 2: } \\
\text { Listening for } \\
\text { specific } \\
\text { information - } \\
\text { multiple choice }\end{array}$ & $\begin{array}{l}\text { Listening to a } \\
\text { dialogue between } \\
\text { Keith and Cathy to } \\
\text { answer the } \\
\text { questions correctly. } \\
\text { Listening to the } \\
\text { dialogue to choose } \\
\text { the correct answer. }\end{array}$ & $\begin{array}{l}\text { Provide the students with } \\
\text { different topics of } \\
\text { situation. Tell them to } \\
\text { choose one topic and write } \\
\text { a strong reason whether } \\
\text { they have to make or } \\
\text { decline the appointment. }\end{array}$ \\
\hline 7 & Telling stories & $\begin{array}{l}\text { Task 1: } \\
\text { Listening for } \\
\text { specific } \\
\text { information - } \\
\text { Multiple choice } \\
\text { Task 2: } \\
\text { Listening for } \\
\text { specific } \\
\text { information - }\end{array}$ & $\begin{array}{l}\text { - Listening to the } \\
\text { story to choose the } \\
\text { correct answer. } \\
\text { - Listening to the } \\
\text { story and stating if } \\
\text { it is true or false } \\
\text { based on the story. }\end{array}$ & $\begin{array}{l}\text { Ask the students } \\
\text { individually to write their } \\
\text { unforgettable experience. }\end{array}$ \\
\hline
\end{tabular}




\begin{tabular}{|c|c|c|c|c|}
\hline & & $\begin{array}{l}\text { ticking true or } \\
\text { false }\end{array}$ & & \\
\hline 8 & $\begin{array}{l}\text { Expressing } \\
\text { happiness }\end{array}$ & $\begin{array}{l}\text { Task 1: } \\
\text { Listening for } \\
\text { specific } \\
\text { information - } \\
\text { completing } \\
\text { chart. } \\
\text { Task 2: } \\
\text { Listening for } \\
\text { specific } \\
\text { information - } \\
\text { completing gaps. }\end{array}$ & $\begin{array}{l}\text { Listening to the } \\
\text { recording and write } \\
\text { expression of } \\
\text { happiness. } \\
\text { - Listeningto the } \\
\text { conversation to fill } \\
\text { in the blanks. }\end{array}$ & $\begin{array}{l}\text { Ask the students in } \\
\text { random to mime as the } \\
\text { teacher reads some } \\
\text { expressions of happiness. } \\
\text { Invite other students to } \\
\text { clap for each miming. The } \\
\text { funniest miming is decided } \\
\text { by the most clapping he or } \\
\text { she get from other } \\
\text { students. He or she is the } \\
\text { winner. }\end{array}$ \\
\hline 9 & $\begin{array}{l}\text { Asking for and } \\
\text { showing } \\
\text { attention }\end{array}$ & $\begin{array}{l}\text { Task 1: } \\
\text { Listening for } \\
\text { specific } \\
\text { information - } \\
\text { completing } \\
\text { table. } \\
\text { Task 2: } \\
\text { Listening for } \\
\text { specific } \\
\text { information - } \\
\text { completing gaps }\end{array}$ & $\begin{array}{l}\text { - Listening to the } \\
\text { recording to fill in } \\
\text { the blanks. } \\
\text { Listening to the } \\
\text { recording to match } \\
\text { the phrases. }\end{array}$ & $\begin{array}{l}\text { In pairs, ask the students to } \\
\text { write a dialogue which in } \\
\text { that dialogue contains } \\
\text { asking for or showing } \\
\text { attention }\end{array}$ \\
\hline 10 & Song & $\begin{array}{l}\text { Task 1: } \\
\text { Listening for } \\
\text { specific } \\
\text { information - } \\
\text { matching } \\
\text { phrases }\end{array}$ & $\begin{array}{l}\text { Listening to the } \\
\text { song to complete } \\
\text { the gaps with the } \\
\text { phrases provided. }\end{array}$ & $\begin{array}{l}\text { Invite all the students to } \\
\text { sing a song together. Make } \\
\text { sure that they can sing the } \\
\text { song well and correctly. If } \\
\text { they do not, help them } \\
\text { how or show them the } \\
\text { ways. }\end{array}$ \\
\hline 11 & $\begin{array}{l}\text { Showing } \\
\text { sympathy }\end{array}$ & $\begin{array}{l}\text { Task 1: } \\
\text { Listening for } \\
\text { specific } \\
\text { information - } \\
\text { completing gaps } \\
\text { Task 2: } \\
\text { Listening for } \\
\text { specific } \\
\text { information - } \\
\text { completing gaps. } \\
\text { Task 3: } \\
\text { Listening for } \\
\text { specific } \\
\text { information - } \\
\text { answering } \\
\text { questions. }\end{array}$ & $\begin{array}{l}\text { - Listening to the } \\
\text { recording to } \\
\text { complete the gaps } \\
\text { in the table. } \\
\text { - Listening to the } \\
\text { recording to fill in } \\
\text { the blanks. } \\
\text { - Listening to the } \\
\text { recording ato } \\
\text { answer the } \\
\text { questions correctly. }\end{array}$ & $\begin{array}{l}\text { Draw a certain situation } \\
\text { orally. Invite the students } \\
\text { to give responds for that } \\
\text { situations orally. }\end{array}$ \\
\hline 12 & $\begin{array}{l}\text { Giving } \\
\text { instruction }\end{array}$ & $\begin{array}{l}\text { Task 1: } \\
\text { Listening for } \\
\text { specific } \\
\text { information - } \\
\text { ordering }\end{array}$ & $\begin{array}{l}\text { - Listening to the } \\
\text { dialogue and } \\
\text { numbering the } \\
\text { instruction. }\end{array}$ & $\begin{array}{l}\text { In pairs, give the students } \\
\text { a number of instructions. } \\
\text { In turn, tell them to read } \\
\text { the instructions and } \\
\text { another student do as }\end{array}$ \\
\hline
\end{tabular}


How to make something

$\begin{array}{ll}\begin{array}{l}\text { Task 1: } \\ \text { Listening for } \\ \text { specific }\end{array} & \begin{array}{l}\text { Listening to the } \\ \text { recording and } \\ \text { numbering the step } \\ \text { information }-\end{array} \\ \begin{array}{l}\text { in cooking rice. } \\ \text { sentences. }\end{array} & \begin{array}{l}\text { Listening to the } \\ \text { procedure of } \\ \text { Task 2: }\end{array} \\ \begin{array}{l}\text { Listening for } \\ \text { specific }\end{array} & \begin{array}{l}\text { stating if it is true or } \\ \text { false. } \\ \text { information }-\end{array} \\ \text { ticking true or } \\ \text { false. }\end{array}$

Task 1:

Listening for specific information ordering Task 2:

Listening for specific ticking true or
Provide a series of picture of "How to make something" for instance how to charge mobile phone battery or how to make chicken nugget and etc. Tell them to explain its procedure.

Table 2: Map of the Recordings on CD

\begin{tabular}{|c|c|c|c|c|}
\hline UNIT & TOPICS & TASKS & TRACKS & NOTES \\
\hline- & - & - & Audio Track 1 & CD 1 \\
\hline \multirow{4}{*}{1} & \multirow{4}{*}{ Greetings and Partings } & Intro to unit 1 & Audio Track 2 & CD 1 \\
\hline & & 1 & Audio Track 3-6 & CD 1 \\
\hline & & 2 & Audio Track $7-10$ & CD 1 \\
\hline & & 3 & Audio Track 11 - 14 & CD 1 \\
\hline \multirow{3}{*}{2} & \multirow{3}{*}{ Introduction } & Intro to unit 2 & Audio Track 15 & CD 1 \\
\hline & & 1 & Audio Track $16-19$ & CD 1 \\
\hline & & 2 & Audio Track 20 - 23 & CD 1 \\
\hline \multirow{4}{*}{3} & \multirow{4}{*}{ Announcement } & Intro to unit 3 & Audio Track 24 & CD 1 \\
\hline & & 1 & Audio Track $25-28$ & CD 1 \\
\hline & & 2 & Audio Track $29-32$ & CD 1 \\
\hline & & 3 & Audio Track $33-36$ & CD 1 \\
\hline \multirow{3}{*}{4} & \multirow{3}{*}{$\begin{array}{l}\text { Talking about past } \\
\text { events }\end{array}$} & Intro to unit 4 & Audio Track 37 & CD 1 \\
\hline & & 1 & Audio Track $38-41$ & CD 1 \\
\hline & & 2 & Audio Track $42-45$ & CD 1 \\
\hline \multirow{3}{*}{5} & \multirow{3}{*}{ Making invitation } & Intro to unit 5 & Audio Track 46 & CD 1 \\
\hline & & 1 & Audio Track $47-50$ & CD 1 \\
\hline & & 2 & Audio Track $51-54$ & CD 1 \\
\hline \multirow{3}{*}{6} & \multirow{3}{*}{$\begin{array}{l}\text { Making or Declining } \\
\text { Appoinment }\end{array}$} & Intro to unit 6 & Audio Track 55 & CD 1 \\
\hline & & 1 & Audio Track $56-59$ & CD 1 \\
\hline & & 2 & Audio Track 60 - 63 & CD 1 \\
\hline \multirow{3}{*}{7} & \multirow{3}{*}{ Telling Stories } & Intro to unit 7 & Audio Track 64 & CD 1 \\
\hline & & 1 & Audio Track $65-68$ & CD 1 \\
\hline & & 2 & Audio Track $69-72$ & CD 1 \\
\hline \multirow{3}{*}{8} & \multirow{3}{*}{ Expressing Happiness } & Intro to unit 8 & Audio Track 1 & CD 2 \\
\hline & & 1 & Audio Track $2-5$ & CD 2 \\
\hline & & 2 & Audio Track 6-9 & CD 2 \\
\hline \multirow{3}{*}{9} & \multirow{3}{*}{$\begin{array}{l}\text { Asking for and } \\
\text { Showing Attention }\end{array}$} & Intro to unit 9 & Audio Track 10 & CD 2 \\
\hline & & 1 & Audio Track $11-14$ & CD 2 \\
\hline & & 2 & Audio Track $15-18$ & CD 2 \\
\hline \multirow{2}{*}{10} & \multirow{2}{*}{ Song } & Intro to unit 10 & Audio Track 19 & CD 2 \\
\hline & & 1 & Audio Track $20-23$ & CD 2 \\
\hline \multirow{3}{*}{11} & \multirow{3}{*}{ Showing sympathy } & Intro to unit 11 & Audio Track 24 & CD 2 \\
\hline & & 1 & Audio Track $25-28$ & CD 2 \\
\hline & & 2 & Audio Track $29-32$ & CD 2 \\
\hline
\end{tabular}




\begin{tabular}{lllll}
\hline & & 3 & Audio Track 33-36 & CD 2 \\
\hline \multirow{2}{*}{$\mathbf{1 2}$} & \multirow{2}{*}{ Giving Instruction } & Intro to unit 12 & Audio Track 37 & CD 2 \\
\cline { 3 - 5 } & & 1 & Audio Track 38 -41 & CD 2 \\
\hline \multirow{2}{*}{$\mathbf{1 3}$} & $\begin{array}{l}\text { How to make } \\
\text { something }\end{array}$ & Intro to unit 13 & Audio Track 42 & CD 2 \\
\cline { 3 - 5 } & 1 & Audio Track 43-46 & CD 2 \\
\cline { 3 - 5 } & & & Audio Track 47-50 & CD 2 \\
\hline
\end{tabular}

\section{The Expert and Teachers Validation}

After the materials were developed based on the needs analysis, then it was validated. The materials validated were the results of teachers' interest and need, students' interest on need analysis. In general, the expert considered that the materials developed were good. It included the style, the content, the language, and the recordings. The expert was an English lecturer. He suggested to revise as soon as possible in order to be able to be tried out. In term of revision, not many things had to be revised. Three things were validated by the expert. He validated first on the evaluation of content. According to him, the evaluation of content were very good. So, he judged it good for all units (unit 1, 2, 3, 4, 5, 6, 7, 8, 9, 10, 11,12 , and 13).Beside the content, the expert also validated the evaluation of language. In this part, he judged it fair for 8 units (unit 1, 2, 4, 6, 7, 10, 11, and 12) and judged it good for 5 units (unit 3, 5, 8, 9, and 13). He judged it fair because there were many mistakes on vocabulary. So, he suggested to check the correctness of the transcription. In relation to the evaluation of style, the expert judged it fair for 6 units (unit 2, 4, 5, 8, 10, and 11) and he judged it good for 7 units (unit 1, 3, 6, 7, 9, 12, and 13). There were some errors on capitalization of words of unit 2 so he suggested to fix it up. Then in accordance with the unit 4, 5 , 8,10 , and 11 , he suggested to put the numbers in brackets.

Two teachers validated the materials. The first teacher commented on the recorded materials that some units were fast that is unit 4,6 , and 13 . The second teacher commented the speed of delivery sometimes does not meet the student's ability because the students were lack of vocabulary and background where they studied in junior high school before. There was no problem from unit 1 to unit 13.Related to the speed of delivery, (appendix 10), the first teacher judged it fair for 3 units $(4,6$, and 13) and judged it good for 10 units $(1,2,3,5,7,8,9,10,11$, and 12). The second teacher judged it fair for 3 units $(4,7$, and 10) and judged it good for other 10 units $(1,2,3,5,6,8,9,11,12$, and 13).Meanwhile, concerning with the length (appendix 11), the first teacher judged it fair for 4 units $(4,6,7$, and 12) and judged it good for other 9 units $(1,2,3,5,8,9,11$, and 13). The second teacher judged it fair for 2 units ( 3 and 7$)$ and judged it good for 11 units $(1,2,4,5,6,8,9,10,11,12$, and 13).

\section{Revision}

In general, the revision was done on the product of the book and only very little thing on the recording that was because there were two sentences missing on the recording of unit 11 for task 2 . The revision on the product of the book was done on several things namely table of content, teacher's note, activities in each unit, and the recording script. In relation with the table of content, teacher's note, activities in each unit, and the recording script, the revision in detail would be described in the following tables. 
Table 3: The revision of the materials on the table of content

\begin{tabular}{|c|c|c|}
\hline $\mathrm{NO}$ & BEFORE REVISION & AFTER REVISION \\
\hline 1 & LIST OF CONTENTS & TABLE OF CONTENTS \\
\hline 2 & Teacher's notes and answers & Teacher's note and introduction \\
\hline 3 & $\begin{array}{l}\text { - } \quad \text { Ticking information : completing gaps. } \\
\text { - Checking informaion: ticking yes/no } \\
\text { question. }\end{array}$ & $\begin{array}{l}\text { Task 1: Completing Gaps } \\
\text { Task 2: Ticking Yes/No Questions. }\end{array}$ \\
\hline
\end{tabular}

Table 4: The revision of the materials on teacher's note

\begin{tabular}{|c|c|c|c|}
\hline $\mathrm{NO}$ & Units & BEFORE REVISION & AFTER REVISION \\
\hline 1 & Introduction & $\begin{array}{l}\text { All the activity in each unit is } \\
\text { based on the listening graded for } \\
\text { the ten graders of senior high } \\
\text { school }\end{array}$ & $\begin{array}{l}\text { All the activities in each unit is based } \\
\text { on the listening graded for the ten } \\
\text { graders of senior high school }\end{array}$ \\
\hline 2 & 1 & $\begin{array}{l}\text { - As a model, teacher pronounce } \\
\text { some expressions about } \\
\text { greetings and partings and } \\
\text { being followed by the students. } \\
\text { - Teacher writes unfamiliar words } \\
\text { on the board then pronounce } \\
\text { them and being followed by the } \\
\text { students. } \\
\text { - Give students time to do the task } \\
1 \text { complete the gaps, } 2 \text { answer } \\
\text { yes or no questions, and } 3 \\
\text { answer questions correctly. } \\
\text { - Answer key }\end{array}$ & 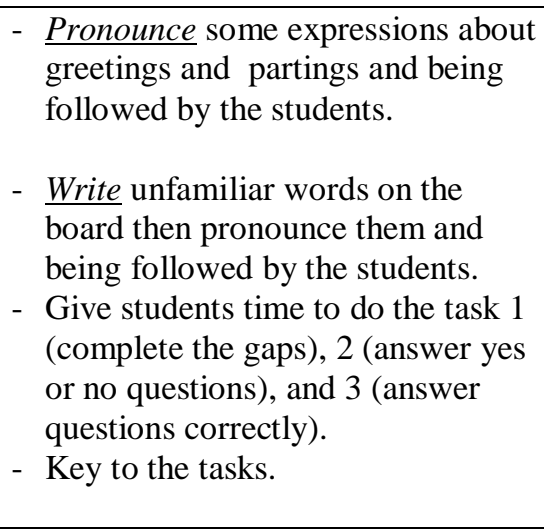 \\
\hline 3 & 2 & $\begin{array}{l}\text { - Teacher introduces herself in } \\
\text { front of the class as a model } \\
\text { - Answer key. }\end{array}$ & $\begin{array}{l}\text { - Introduce herself or himsel in front } \\
\text { of the class as a model. } \\
\text { - Key to the tasks }\end{array}$ \\
\hline 4 & 3 & - Answer key. & - Key to the tasks. \\
\hline 5 & 4 & $\begin{array}{l}\text { - Unit } 4 \text { PAST EVENT. } \\
\text { - Answer key. }\end{array}$ & $\begin{array}{l}\text { - Unit } 4 \text { TALKING ABOUT PAST } \\
\text { EVENT. } \\
\text { - Key to the tasks. }\end{array}$ \\
\hline 6 & 5 & $\begin{array}{l}\text { - Teacher pronounces them and } \\
\text { followed by the students. } \\
\text { - Answer key. }\end{array}$ & $\begin{array}{l}\text { - } \frac{\text { Pronounce them and followed by }}{\text { the students. }} \\
\text { - Key to the tasks. }\end{array}$ \\
\hline 7 & 6 & $\begin{array}{l}\text { - Unit } 6 \text { MAKING OR } \\
\text { DECLINING APPOINMNET. } \\
\text { - } \text { Answer key. }\end{array}$ & $\begin{array}{l}\text { - Unit } 6 \text { MAKING OR DECLINING } \\
\text { APPOINTMENT. } \\
\text { - } \text { Key to the tasks. }\end{array}$ \\
\hline 8 & 7 & $\begin{array}{l}\text { - Teacher writes the title of the } \\
\text { story and unfamiliar words on } \\
\text { the board. } \\
\text { - Teacher pronounces them and } \\
\text { being followed by the students. } \\
\text { Then translate them all. } \\
\text { - Answer key. }\end{array}$ & $\begin{array}{l}\text { - Write the title of the story and } \\
\text { unfamiliar words on the board. } \\
\text { - Pronounce them and being } \\
\text { followed by the students. Then } \\
\text { translate them all. } \\
\text { - Key to the tasks. }\end{array}$ \\
\hline 9 & 8 & - Answer key. & - Key to the tasks. \\
\hline 10 & 9 & - Answer key. & - Key to the tasks. \\
\hline 11 & 10 & - Answer key. & - Key to the tasks. \\
\hline 12 & 11 & $\begin{array}{l}\text { - Teacher says some examples of } \\
\text { expressions of showing } \\
\text { sympathy followed by the } \\
\text { students. } \\
\text { - Answer key. }\end{array}$ & $\begin{array}{l}\text { - Pronouncesome examples of } \\
\text { expressions of showing sympathy } \\
\text { followed by the students. } \\
\text { - Key to the tasks. }\end{array}$ \\
\hline
\end{tabular}




\begin{tabular}{llll}
\hline \multirow{2}{*}{13} & \multirow{2}{*}{12} & $\begin{array}{l}- \\
\text { Invite two or three students to } \\
\text { come forwards. }\end{array}$ & $\begin{array}{l}\text { - } \begin{array}{l}\text { Invite two or three students to } \\
\text { come forward. }\end{array} \\
-\end{array}$ \\
\hline 14 & 13 & - Answer key. & - Key to the tasks. \\
\hline
\end{tabular}

Table 5: The revision of the materials on activities in each units

\begin{tabular}{|c|c|c|c|c|}
\hline $\mathrm{NO}$ & Units & Tasks & BEFORE REVISION & AFTER REVISION \\
\hline 1 & 2 & 1 & $\begin{array}{l}\text { - Malik: } 1 \text {, my name is } \\
\text { Malik } \\
\text { Helen: Hi, my name is Helen. }\end{array}$ & $\begin{array}{l}\text { - Malik: }(\underline{\boldsymbol{1}}) \text {, my name is Malik } \\
\text { Helen: Hi, my name is Helen. }\end{array}$ \\
\hline 2 & 4 & 1 & $\begin{array}{l}\text { - David: What did you } 1 \\
\text { yesterday John? }\end{array}$ & $\begin{array}{l}\text { - David: What } \operatorname{did}(\mathbf{1}) \\
\text { today John? }\end{array}$ \\
\hline 3 & 5 & 1 & $\begin{array}{l}\text { - The international students } \\
\text { association is having a party on } \\
\text { Saturday night. } 1\end{array}$ & $\begin{array}{l}\text { - The international students } \\
\text { association is having a party on } \\
\text { Saturday night. }(\underline{1)} ?\end{array}$ \\
\hline 4 & 8 & 2 & $\begin{array}{l}\text { - Yeah. My daugther Maggie } \\
\text { made that family tree for a } \underline{1} \\
\text { school. }\end{array}$ & $\begin{array}{l}\text { - Yeah. My daugther Maggie } \\
\text { made that family tree for a (1) } \\
\text { school. }\end{array}$ \\
\hline 5 & 10 & 1 & - A hole $\underline{1}$ & - A hole $(\underline{1)}$ \\
\hline 6 & 11 & 1 & $\begin{array}{l}\text { - W: Yes, I heard about it too. It } \\
\text { was } 1\end{array}$ & $\begin{array}{l}\text { - W: Yes, I heard about it too. It } \\
\text { was (1) }\end{array}$ \\
\hline
\end{tabular}

Table 6: The revision of the materials on the recording script

\begin{tabular}{ccclc}
\hline NO & Units & Tasks & \multicolumn{1}{c}{ BEFORE REVISION } & AFTER REVISION \\
1 & All & All & $\begin{array}{l}\text { No instructions before the all } \\
\text { Tasks in each unit }\end{array}$ & $\begin{array}{c}\text { The instructions are added in each } \\
\text { unit }\end{array}$ \\
\hline 2 & 1 & 3 & No recording script & The recording script is added \\
\hline
\end{tabular}

Table 7: The revision of the materials on the mp3 or recordings

\begin{tabular}{|c|c|c|c|c|}
\hline NO & Units & Tasks & BEFORE REVISION & AFTER REVISION \\
\hline 1 & - & - & Semester 1 & Semester one \\
\hline 2 & 11 & 2 & $\begin{array}{l}\text { W: What's the matter with you, } \\
\text { Rudy? } \\
\text { M: I had an accident last night? }\end{array}$ & $\begin{array}{l}\text { W: What's the matter with you, } \\
\quad \text { Rudy? } \\
\text { M: I had an accident last night? }\end{array}$ \\
\hline
\end{tabular}

\section{The result of the Try out}

In generals the try out talked about the researcher's observation, students' opinion about the materials, students' task and teachers' opinion about the materials. There were 13 units of the developed materials. Four units only were tried out. It was unit 1, 2, 7, and 13. They were chosen because in those four units could cover all activities in each unit of 13. During the try out, the researcher just sat and observed all the activities occurring at the process of teaching and learning. He was not involved at all because he wanted to know if the developed materials was effective, efficient, and practical enough to teach listening. What he did was only observed and made some notice for the data.

After the try out was finished, the students were asked to answer some questions about the tried out materials. According to students' opinion the materials were attractive enough. More specifically the attractiveness on the materials were $67.5 \%$ of the students considered very well, $25 \%$ were good, and 
$7.5 \%$ considered them fair. Meanwhile, for the clarity of the recording, $75 \%$ students considered very well, $15 \%$ considered them good, and $10 \%$ considered them fair. Concerning with the speed of delivery, $17.5 \%$ of the students considered that the materials were very good, $50 \%$ considered them good, and $12.5 \%$ considered them fair. Besides the attractiveness, the clarity of the recording, and the speed of delivery, the researcher considered that the vocabulary usage and the difficulty of the materials were very important. Based on the observation it was obtained that $37.5 \%$ of the students considered that the vocabulary usage of the materials were very easy, $50 \%$ considered them easy, and $12.5 \%$ considered them fair. In relation to the difficulty of the materials, $27.5 \%$ of the students considered that the materials were very difficult, $52.5 \%$ considered them difficult, and $20 \%$ considered them fair.

During the try out, the students enjoyed a lot because they were never taught listening before for a year. When the try out was finished, the students were asked to collect their works then the researcher calculated how many of them were making mistakes on unit 1 task 1, 2, and 3, unit 2 task 1 and 2, unit 7 task 1, and 2, and unit 13 task 1 and 2 . Actually the students were good at listening. The result of their work was not disappointing. For unit 1 task 1 , the students in total made $13.75 \%$ mistakes among 80 items of the gap filling activities, unit 1 task 2 they made $18 \%$ mistakes among 50 items of questions, unit 1 task 3 they made $20 \%$ mistakes among 50 items questions. Meanwhile, for unit 2 task 1, the students made $20 \%$ mistakes among 60 items of gap filling activities and for unit 2 task 2, they made $23.3 \%$ mistakes among 100 items of matching halves sentences activities.

In unit 7 there were 5 questions of multiple choice and 5 questions of ticking true or false. For unit 7 task 1, the students made $20 \%$ mistakes among 50 items of multiple choice and for unit 7 task 2, they made $24 \%$ mistakes among 50 items of ticking true and false activities.Then for unit 13 task 1, the students made $22 \%$ mistakes among 50 items of ordering sentences and they made $20 \%$ mistakes of ticking true or false for unit 13 task 2.

\section{The Final Product}

After all steps in doing research was over, the final product of the listening materials were presented. It was presented after the validation process form the expert, his comments and suggestions, and the try out. The final product can be seen from the following table.

Table 8: The content of Students' Worksheet

\begin{tabular}{|c|c|c|c|}
\hline UNIT & TOPICS & TASKS & ACTIVITIES \\
\hline 1 & $\begin{array}{l}\text { Greetings and } \\
\text { Partings }\end{array}$ & $\begin{array}{l}\text { Task 1: listening for specific } \\
\text { information - completing } \\
\text { gaps. } \\
\text { Task 2: listening for specific } \\
\text { information - ticking yes/no } \\
\text { questions. } \\
\text { Task 3: listening for specific } \\
\text { information - answering } \\
\text { questions. }\end{array}$ & $\begin{array}{l}\text { Listening to the recording and } \\
\text { completing the gaps in the table. } \\
\text { - Listening to the short } \\
\text { conversation and answer the } \\
\text { questions with yes or no answer. } \\
\text { - Listening to the short } \\
\text { conversation again and answer the } \\
\text { questions correctly. }\end{array}$ \\
\hline 2 & Introduction & $\begin{array}{l}\text { Task 1: listening for specific } \\
\text { information - completing }\end{array}$ & $\begin{array}{l}\text { Listening to the several } \\
\text { conversations to fill in the blanks. }\end{array}$ \\
\hline
\end{tabular}




\begin{tabular}{|c|c|c|c|}
\hline & & $\begin{array}{l}\text { gaps. } \\
\text { Task 2: listening for specific } \\
\text { information - matching half } \\
\text { sentences. }\end{array}$ & $\begin{array}{l}\text { - Listening to the recording and } \\
\text { match half sentences. }\end{array}$ \\
\hline 3 & Announcement & $\begin{array}{l}\text { Task 1: listening for specific } \\
\text { information -completing } \\
\text { chart. } \\
\text { Task 2: listening for specific } \\
\text { information - multiple choice. } \\
\text { Task 3: listening for specific } \\
\text { information - putting the } \\
\text { number in the correct places. }\end{array}$ & $\begin{array}{l}\text { - Listening to the announcement of } \\
\text { job vacancy to complete the chart. } \\
\text { - Listening to the announcement } \\
\text { and choose the best answer. } \\
\text { - Listening again to the } \\
\text { announcement and putting the } \\
\text { number in the correct places. }\end{array}$ \\
\hline 4 & $\begin{array}{l}\text { Talking about } \\
\text { past event }\end{array}$ & $\begin{array}{l}\text { Task 1: listening for specific } \\
\text { information - completing } \\
\text { gaps. } \\
\text { Task 2: listening for specific } \\
\text { information - answering } \\
\text { questions. }\end{array}$ & $\begin{array}{l}\text { - Listening to short conversations to } \\
\text { fill in the gaps. } \\
\text { - Listening to the monologue text } \\
\text { then answer the questions } \\
\text { correctly. }\end{array}$ \\
\hline 5 & $\begin{array}{l}\text { Making } \\
\text { invitation }\end{array}$ & $\begin{array}{l}\text { Task 1: Listening for specific } \\
\text { information - completing gaps } \\
\text { Task 2: Listening for specific } \\
\text { information - ticking true or } \\
\text { false }\end{array}$ & $\begin{array}{l}\text { - Listening to several short } \\
\text { dialogues to fill in the gaps. } \\
\text { - Listening the dialogue and stating } \\
\text { if it is true or false based on the } \\
\text { dialogue. }\end{array}$ \\
\hline 6 & $\begin{array}{l}\text { Making or } \\
\text { declining } \\
\text { appointment }\end{array}$ & $\begin{array}{l}\text { Task 1: Listening for specific } \\
\text { information - answering } \\
\text { questions } \\
\text { Task 2: Listening for specific } \\
\text { information - multiple choice }\end{array}$ & $\begin{array}{l}\text { - Listening to a dialogue between } \\
\text { Keith and Cathy to answer the } \\
\text { questions correctly. } \\
\text { - Listening to the dialogue to } \\
\text { choose the correct answer. }\end{array}$ \\
\hline 7 & Telling stories & $\begin{array}{l}\text { Task 1: Listening for specific } \\
\text { information - Multiple choice } \\
\text { Task 2: Listening for specific } \\
\text { information - ticking true or } \\
\text { false }\end{array}$ & $\begin{array}{l}\text { - Listening to the story to choose } \\
\text { the correct answer. } \\
\text { - Listening to the story and stating } \\
\text { if it is true or false based on the } \\
\text { story. }\end{array}$ \\
\hline 8 & $\begin{array}{l}\text { Expressing } \\
\text { happiness }\end{array}$ & $\begin{array}{l}\text { Task 1: Listening for specific } \\
\text { information - completing } \\
\text { chart. } \\
\text { Task 2: Listening for specific } \\
\text { information - completing } \\
\text { gaps. }\end{array}$ & $\begin{array}{l}\text { Listening to the recording and } \\
\text { write expression of happiness. } \\
\text { Listening to the conversation to } \\
\text { fill in the blanks. }\end{array}$ \\
\hline 9 & $\begin{array}{l}\text { Asking for and } \\
\text { showing } \\
\text { attention }\end{array}$ & $\begin{array}{l}\text { Task 1: Listening for specific } \\
\text { information - completing } \\
\text { table. } \\
\text { Task 2: Listening for specific } \\
\text { information - completing gaps }\end{array}$ & $\begin{array}{l}\text { - Listening to the recording to fill in } \\
\text { the blanks. } \\
\text { - Listening to the recording to } \\
\text { match the phrases. }\end{array}$ \\
\hline 10 & Song & $\begin{array}{l}\text { Task 1: Listening for specific } \\
\text { information - matching } \\
\text { phrases }\end{array}$ & $\begin{array}{l}\text { - Listening to the song to complete } \\
\text { the gaps with the phrases } \\
\text { provided. }\end{array}$ \\
\hline 11 & $\begin{array}{l}\text { Showing } \\
\text { sympathy }\end{array}$ & $\begin{array}{l}\text { Task 1: Listening for specific } \\
\text { information - completing gaps } \\
\text { Task 2: Listening for specific } \\
\text { information - completing } \\
\text { gaps. } \\
\text { Task 3: Listening for specific } \\
\text { information - answering } \\
\text { questions. }\end{array}$ & $\begin{array}{l}\text { - Listening to the recording to } \\
\text { complete the gaps in the table. } \\
\text { - Listening to the recording to fill in } \\
\text { the blanks. } \\
\text { - Listening to the recording ato } \\
\text { answer the questions correctly. }\end{array}$ \\
\hline 12 & $\begin{array}{l}\text { Giving } \\
\text { instruction }\end{array}$ & $\begin{array}{l}\text { Task 1: Listening for specific } \\
\text { information - ordering }\end{array}$ & $\begin{array}{l}\text { - Listening to the dialogue and } \\
\text { numbering the instruction. }\end{array}$ \\
\hline
\end{tabular}




\begin{tabular}{|c|c|c|c|}
\hline & & sentences & \\
\hline 13 & $\begin{array}{l}\text { How to make } \\
\text { something }\end{array}$ & $\begin{array}{l}\text { Task 1: Listening for specific } \\
\text { information - ordering } \\
\text { sentences. } \\
\text { Task 2: Listening for specific } \\
\text { information - ticking true or } \\
\text { false. }\end{array}$ & $\begin{array}{l}\text { - Listening to the recording and } \\
\text { numbering the step in cooking } \\
\text { rice. } \\
\text { - Listening to the procedure of } \\
\text { cooking jelly and stating if it is } \\
\text { true or false. }\end{array}$ \\
\hline
\end{tabular}

\section{CONCLUSION}

The steps adapted cover need analysis, developing materials, expert and teacher's validation, revision, try out, and the final product. The product of this study is teacher's book, student's worksheet, and the recording which is recorded in CD. The criteria of choosing the materials is based on Underwood (1993b). They are the language, length, content, style, and speed of delivery, the style of delivery and the quality of the recording. Concerning with the tasks in each unit follows some examples of activities proposed by Morley. (1984).

Some recommendation are for further researcher and the teachers. Further researchers are able to conduct similar study to develop listening materials which this study can be a reference for them since their focus is still on listening materials; the teachers who will use the result of this study or this product assure that when the students are listening, they have a special aims on certain tasks for listening.

\section{REFERENCES}

Anderson, A. and Lynch, T. 1988. Listening. Oxford: Oxford University Press.

Brown, H. D. 2007. Teaching by Principles: An Interactive Approach to Language Pedagogy. New York: Pearson Education.

Cahyono. B.Y and Widiati. U. 2011. The Teaching of English as a Foreign Language in Indonesia. Malang: State University of Malang.

Departemen Pendidikan Nasional. 2006. Standar Isi danStandarKompetensiLulusan Tingkat SMA/MA (The Standard of Content and The Standard of Graduate Competence for SMA/MA). Jakarta: Binatama Raya.

Fang, X. 2008. Listening Comprehension in EFL Teaching. Retrieved February $30^{\text {th }}$, 2010 from: The Internet TESL Journal, Vol VI, No, 200

Harmer, J. 2007. The Practice of English Language Teaching. England: Longman.

Hartani, T. 1999. Developing Teaching Materials based on a Proposed English Listening Comprehension Syllabus for Secretary Academy Students. Unpublished Thesis. Graduate Program in English Education. State University of Malang.

Helgessen, M 2003. Teaching Listening. In D. Nunan. Practical English Language Teaching. New York: McGraw-Hill

Hyland, K. 2003. Second Language Writing. Cambridge: Cambridge University Press. 
Latief. M. A. 2011. Tanya Jawab Metode Penelitian Pembelajaran Bahasa. Malang: State University of Malang.

Morley. J. 1984. Listening and Language Learning in ESL. Developing self-study Activities for Listening Comprehension. New York: Havcourt Brace Jovanovich

Nunan, D. 1998. The Learner Centered Curriculum. A Study in Second Language Teaching. Cambridge: Cambridge University Press.

Nunan, D. 1999. Second Language Teaching and Learning. Boston: An International Thompson.

Nunan, D. (Eds.). 2003. Practical English Language Teaching. First Edition. New York. Prentice Hall.

Richards, J.C. 2001. An Approaches and Methods in Language Teaching. Cambridge: Cambridge University Press.

Rosyidah, A. 2002. Developing Listening Materials for Teaching English at MAN Malang I. Unpublished Thesis. Graduate Program in English Education. State University of Malang

Underwood, M. 1993a. Teaching Listening. London and New York: The Macmillan Company.

Ur, P. 2002. A Course in Language Teaching. Cambridge: Cambridge University Press.

Zaenuri, M. 2008. Developing EFL Listening Materials for the Seventh Grade Students of MTs NegeriMojokerto. Unpublished Thesis. Graduate Program in English Education. State University of Malang. 